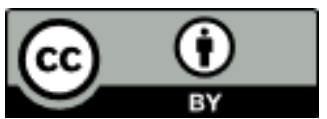

Mario Brdar1

Rita Brdar-Szabó2

1 University of Osijek

${ }^{2}$ Eötvös Loránd University, Budapest
UDC 811.111'373.612.2=111

$811.111^{\prime} 42: 61=111$

Original scientific article

Accepted for publication on 26.09 .2020 https://doi.org/10.29162/jez.2020.10

\title{
The role of metaphors and metonymies in framing the transplantation discourse*
}

This article studies figurative uses of metaphors and metonymies utilized to frame the discourse of transplantology. We assume a somewhat wider view of framing than is usually found in the literature and argue that framing effects can be observed on a cline stretching from the private to the institutional pole. We combine this approach with the findings of the prospect theory that distinguishes between gain-framing and loss-framing as two strategic choices in tackling an issue in discourse. The framing tools, as we show in our analysis of authentic materials, in order to be effective need to be adapted to the section of, or the point on, the cline occupied by a particular subtype of discourse. Although the focus in the cognitive linguistic literature is on how conceptual metaphors are employed in framing discourse, we point out that metonymies, interacting with these metaphors, can also play a very important role. The framing tools used in public campaign aimed at winning new organ donors are strategically mostly gain-framed, and as a rule globally based on the GIFT metaphor. It seems that the metaphorical use of GIFT as a global choice in institutional contexts is not very efficient since it is too general and vague to make discourse more persuasive at the personal level, as expected in the light of the exemplification theory. This metaphor is more effective when adapted accordingly, as we demonstrated on some campaigns supported by or

* Financed by FEDER/Spanish Ministry of Science, Innovation and Universities, State Research Agency, project no. FFI2017-82730-P. This article has also been fully supported by the internal research grant UNIOS-ZUP 2018-77 Figurative Language in Health Communication by the University of Osijek, directed by the first author. 
Mario Brdar - Rita Brdar-Szabó:

The role of metaphors and metonymies in framing the transplantation discourse

based on metonymic presentation of various aspects stressing the quality of life after transplantation.

Key words: metaphor; metonymy; framing; medical discourse.

\section{Introduction: figurative language in medical discourse in general as well as especially in the transplantation discourse ${ }^{1}$}

In this article we study strategic uses of figurative language, chiefly conceptual metaphors and conceptual metonymies, in steering the discourse of transplantology, the branch of medicine that deals with procedures for organ/tissue transplantation, specifically public discourse of campaigns and materials by various institutional participants (national health administration, hospitals, etc.) aimed at winning people to join organ donation schemas. The need for such campaigns and materials is obvious considering the ratio of transplantable organs that are available and the number of patients on waiting lists (Thompson 2003: 1). As pointed out by Morgan, Harrison, Chewning, Davis and DiCorcia (2007: 143),

[y] ear after year, studies of American attitudes toward organ donation indicate nearly universally strong support $(80 \%-90 \%, \ldots)$. Yet, when asked to make a decision, only about $30 \%$ to $50 \%$ of people consent to the donation of the organs of a loved one (...), and even fewer (about 30\%) actually sign a donor card or join an organ donor registry to declare an intent to donate one's own organs after death (...). This wide gap between attitudes and behaviors has been largely ignored by researchers in this area.

The situation has not changed for the better since then, as reported by Steffel et al. (2019: 17): "In the United States, more than 148,000 people have died since 1995 while waiting for a suitable donor, and the gap between those who remain on the waiting list and those who receive transplants continues to widen..." This is obvious from the figure they cite (Organ Donation and Transplantation Statistics: Graph Data, by U.S. Government Information on Organ Donation and Transplantation, 2019, available from the public domain https://www.organdonor. gov/statistics-stories/statistics/data.html):

\footnotetext{
${ }^{1}$ We are grateful to the two anonymous referees of Jezikoslovlje for their insightful comments and constructive suggestions on the earlier draft of this article. Any remaining errors are ours.
} 
Figure 1. Candidates on waiting list for organ transplant, transplants, \& donors in the United States between 1989 and 2017

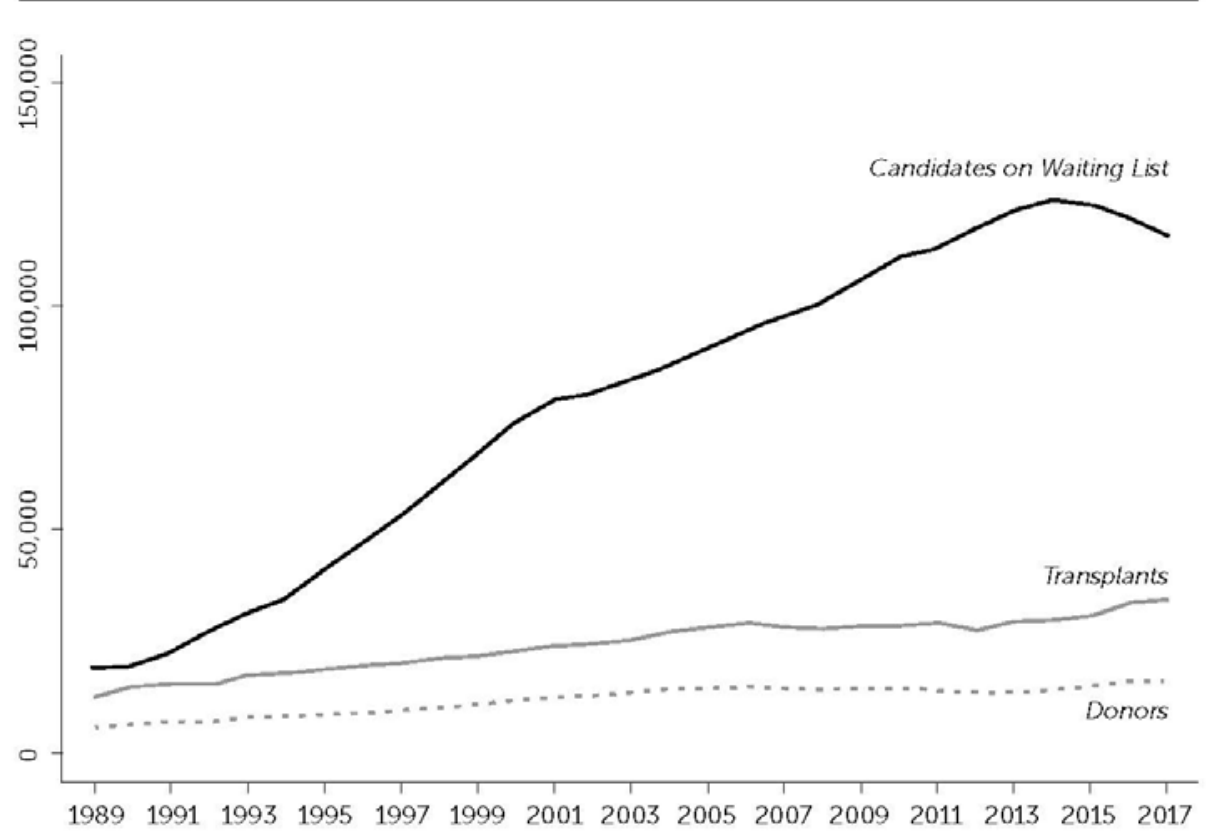

Figure 1. Candidates on waiting list for organ transplant, transplants \& donors in the United States between 1989 and 2017 (Steffel et al. 2019: 17)

As in medical discourse in general, figurative language in transplantology has a number of important functions. First of all, both metaphors and metonymies can be used as part of medical terminology, where they can be more or less conventionalized. Note that the term organ transplantation, to be discussed in more detail in Section 2 below, is itself metaphorical. Further, domino transplant is the term applied to a situation in which an organ is removed from one transplant candidate and immediately transplanted into a second patient, with the first patient receiving a new organ from a deceased donor. The name Chimera from Greek mythology, where it was used to denote a creature that had the body of a lion, a goat's head and a tail in the form of a serpent, at the end of which was a viper's head, is often used metaphorically in general language to refer to entities that are hybrids and/or exhibit properties coming from more than one source. In transplantology, this term (alternating with the expression genetic chimerism) is used to refer to patients in whose bodies we find cells of different genotype (exhibiting different DNA), as a result of bone marrow or organ transplantation, or as a concept on which future 
treatments may be based (e.g. transplanting tissue or organs grown in animals to humans). The American Society of Transplant Surgeons even adopted the name Chimera as the title of its official online magazine that provides the members with the relevant news concerning the society and the field of transplantation.

The expression transplant, primarily used to refer to the act or process of transplanting, can also be used metonymically to refer to the organ that was transplanted (cf. In group A, the transplant was stable though slightly reduced in size in all patients), or even to the patient undergoing transplantation (cf. In some transplants, for example young children and also bone marrow transplants, ABO compatibility is not a necessity). We also note that death can be used metonymically to refer not to the clinical event but to the person dying, as shown by examples like The percentage of times a death meeting eligible criteria (eligible death) becomes an actual donor. Needless to say, there are numerous eponyms (terms for clinical conditions or procedures based on the names of people closely associated with them, e.g. a disease may be called after a physician who first described it). To give an example an eponym also relevant in transplantology, the Cockcroft-Gault equation or formula (combining the names of the American asthmologist Donald William Cockcroft and the nephrologist Matthew Henry Gault) is used to estimate creatinine clearance as a way of assessing residual kidney function. This eponym is often used in its truncated form, apparently as a metonym, as in For comparison with the prediction of other formulas, the predicted creatinine clearance by CockcroftGault was normalized per $1.73 \mathrm{~m}^{2}$ of BSA using the ...

In addition to this terminological function, both conceptual metaphor and metonymy can have a metacommunicative function in medical discourse, as they can help forge closer links between health practitioners and patients, i.e. establish a closer rapport between them. It seems that

[m]etaphors may be as necessary to illness as they are to literature, as comforting to the patient as his own bathrobe and slippers. At the very least, they are a relief from medical terminology. ... Perhaps only metaphor can express the bafflement, the panic combined with beatitude, of the threatened person. (Broyard 1992, cited in Taylor 2017: 97)

Figurative expressions can be used euphemistically, to cover-up some unpleasant facts, and in that case metaphor can hardly be said to make possible new insights - it actually comes quite close to metonymy in providing alternative means of referring to a phenomenon in a more or less offensive or palatable way. Euphemisms can be based on both metaphors and metonymies, as shown by Fernandez 


\section{EZIKOSLOVLJE \\ 21.3 (2020): 305-344}

Crespo (2006), Portero Muñoz (2011), Gradečak-Erdeljić and Milić (2011), Silaški (2011), or by Kružić and Tanacković Faletar (2019).

Figurative language can, however, also have another important metacommunicative function as it can be used to frame discourse in a particular way, and this is also true of various subtypes of medical discourse. As we show in Section 3 below, framing the discourse of transplantation, as well as the discourse about transplantation, can be very important and have serious implications. We assume in this article a somewhat wider view of framing than is usual in the literature and argue that framing effects can be observed on a cline stretching from the individual to the institutional pole. The framing tools, as we show in our analysis in Section 4, in order to be effective need to be adapted to the section of, or the point on, the cline occupied by a particular subtype of discourse. Although the focus in the literature is on how conceptual metaphors are employed in framing discourse, we point out that metonymies, interacting with these metaphors, can also play a very important role. Summing up our goals, we can formulate 2 research questions:

1. Can the two notions of framing be brought together in a way that promises to be fruitful as far as linguistic analyses are concerned?

2. What is the role of metonymy in framing, e.g. specifically in switching to a loss-frame or in achieving exemplification?

The present article is organized as follows. After this introduction, we briefly introduce the phenomena of conceptual metaphors and metonymies by contrasting them. This is followed by a short section on the sources of data we use and their identification. The final part of Section 2 is an overview of dominant types of conceptual metaphors used in the transplantation discourse. Figurative framing as a discourse phenomenon is introduced in Section 3. We point out the significance of framing in the transplantation discourse and illustrate what we mean by the framing cline stretching from the private to the institutional. In Section 4 we analyse the framing role of metaphors and metonymies in some authentic materials. We sum up our findings, drawing some conclusions and recommendations in Section 5. 


\section{Conceptual metaphors and metonymies in the transplantation discourse}

\subsection{On conceptual metaphors and metonymies}

Within the cognitive linguistic framework, metaphor and metonymy have been contrasted with respect to four central points of difference, although it has been repeatedly claimed that the borderline between the two is blurred (cf. Barcelona 2000a and 2000b; Ruiz de Mendoza 2000). It is widely accepted that metonymy is based on contiguity or association, whereas metaphor is based on similarity. The two also differ in terms of the number of conceptual domains involved. The standard view is that a metonymic mapping occurs within a single domain, while metaphoric mappings take place across two discrete domains.

Metaphor and metonymy are generally different with respect to the directionality of conceptual mappings involved. Metaphors typically employ a more concrete concept or domain as source in order to structure a more abstract concept or domain as target. In the majority of cases, elements from the physical world are mapped onto the social and mental world. Metaphorical mappings are thus normally unidirectional, and the source and target are not reversible (cf. Kövecses 2002: 6). Metonymic mappings can, in principle, proceed in either direction, from the more concrete part of the domain (subdomain) to the more abstract one and the other way round, but of course not simultaneously. According to Radden and Kövecses (1999: 22), "[i]n principle, either of the two conceptual entities related may stand for the other, i.e., unlike metaphor, metonymy is basically a reversible process."

Another crucial point of difference between metaphor and metonymy has to do with the number of mappings taking place: metaphors may work on the basis of a set of correspondences (though some may exploit only one), while metonymic mappings are based on a single correspondence (cf. Ruiz de Mendoza \& Peña 2002).

Metaphor and metonymy are also said to have different functions. Lakoff and Johnson (1980: 36) say that metaphor is "principally a way of conceiving of one thing in terms of another, and its primary function is understanding," while metonymy "has primarily a referential function, that is, it allows us to use one entity to stand for another." However, both of the above statements have to be relativized. While Lakoff and Johnson see metonymy as having primarily referential function they are aware of its additional functions and point out not only that metonymy is "naturally suited for focussing" (Lakoff \& Johnson 1980: 37), but that it can just 
like metaphor have a role in construal. It makes it possible for us to see and understand things in alternative ways.

Finally, due to the fact that metonymy is based on contiguity, while metaphor is based on similarity obtaining between conceptually discrete, and therefore conceptually distant, domains, the type of polysemy these two cognitive operations bring about is very different. In the case of a conceptual metaphor, for any domain that can function as the target domain, we may expect to have more than one potential source domain, e.g. TIME can be conceptualized as MOVEMENT, COMMODITY, PHYSICAL OBJECT, etc. Conversely, one and the same source domain can be used for different target domains, e.g. we can use the domain of MOVEMENT, more specifically JOURNEY to metaphorically conceptualize TIME, LOVE, etc. However, there is not much regularity of what can be used metaphorically to conceptualize something else, and what not, and as a result of this metaphors brings about a more ad hoc type of polysemy of lexical items associated with the source domain. The conceptual distance in the case of metonymy is smaller (we remain within a single domain), and the number of choices is relatively restricted. As a result, metonymic shifts within similar specific domains will tend to be very similar, and the lexical items enjoying the same ontological status within these domains will behave in the similar way, i.e. they will function as metonymic vehicles exhibiting the same type of shift (e.g. lexical items denoting some types of minerals, plants, etc. will come to denote some objects made from them), resulting in more regularity. This is not to deny the systematicity of conceptual metaphors. We know very well that they can be organized in whole systems, but the dominant organizing principle is hierarchy, i.e. the systematicity is "vertical:" a general metaphor can be a family of related submetaphors (their source domain can be quite different), and these can exhibit a number of more specific mappings (which are sometimes considered to be very specific metaphors in their own right) which link to a multitude of lexical items associated with the domains involved. On the other hand, the systematicity of metonymies is of the "horizontal" type.

\subsection{Finding instances of figurative speech in transplantation discourse}

In this subsection we first explain why we refrain from using any classic version of a corpus linguistic approach, and then specify the set of procedures we used for finding instances of figurative speech.

The data used in this study are of necessity heterogeneous, i.e. they often cross the boundaries of modalities. This already makes it extremely difficult to conceive it as a corpus that could lend itself to a characterization in quantitative terms, i.e. by 
specifying the number of "texts" or words it contains (as it is often put, a picture may be worth a thousand words). What we make use of is a collection of examples excerpted from various sources that we found relevant for our purposes in the present article. The data are, however, obviously homogenous in terms of their genre they are persuasive utterances forming part of various public campaigns attempting to change the stance concerning organ donation in favour of increasing the willingness to participate in such donation schemas, or as part of brochures helping transplantees(-to-be).

In fact, in the light of our goals in this article, there is no need for quantitative data as such. Our goal is not to establish that, for example, a conceptual metonymy is used more frequently than a conceptual metaphor, or the other way around, in the above types of texts as a framing device, or in general. Rather, our main goal is to demonstrate that conceptual metonymy, not studied so far as a framing device at all in the literature (though cf. Brdar \& Brdar-Szabó 2004 and Brdar 2007, where alternative construal by means of metonymy is shown to result in differential ascription of responsibility), has an important role to play here, alone and in conjunction with conceptual metaphor. Studying precise quantitative relations between individual types of metonymies and metaphors in this and similar genres or text types in which framing takes place is a task for some future investigations in the wake of this pilot study. As demonstrated in Brdar-Szabó and Brdar (2012), cognitive linguistics may profit from the introspection-driven research and the authentic-data driven research in feeding into each other in a cyclic way (cf. Kertész \& Rákosi 2008: 214; 2009).

It is obvious from what we have just said in this section that finding/identifying examples of figurative speech relevant for our purposes had to be scaled and adapted to the goals of the article. A number of approaches have been developed in cognitive linguistic research that promise to recognize and/or identify figurative expressions in discourse, chiefly conceptual metaphors, but also conceptual metonymies (cf. Berber Sardinha 2008, 2012; Markert \& Nissim 2006; Shutova \& Sun 2013; Shutova et al. 2013; Stefanowitsch 2004, 2006; Steen 2007; Steen et al. 2010; Wallington et al. 2003; Brdar et al. 2020).

According to Berber Sardinha (2012), major techniques and tools for retrieving metaphors from corpora can be characterized either as sampling techniques, or as census techniques. Sampling is "the selection of a fraction of the total number of units of interest to decision makers for the ultimate purpose of being able to draw general conclusions about the entire body of units" (Parasuraman et al. 2004: 333). Census techniques, on the other hand, are those in which "every population unit is examined" (Parasuraman et al. 2004: 359), i.e. researchers have to analyse each token in the corpus. Probably the best-known census method is MIP (Metaphor Iden- 
tification Procedure, cf. Steen et al. 2010). This is actually a fairly complex and laborious (but not automatable) technique proceeding in several explicit steps that aim at establishing, for each lexical unit in a stretch of discourse, whether it is used in the particular context as metaphorical or not. We need not go into the details of all of these steps, but what is relevant for us is that the entire text/ document is first read by the human researcher(s) in order to establish a general understanding of the meaning. Next, lexical units in the text/discourse are determined. For each lexical unit in the text, its meaning in context is established and compared with its basic meaning. If the contextual meaning found in the text in question contrasts with the basic meaning but can be understood in comparison with it, the item is marked as metaphorical. Our approach in the present article can be best characterized as a combination of MIP with what Kövecses et al. (2019) call the lexical approach, an updated version of the classic intuitive approach to metaphor identification.

\subsection{Dominant types of metaphors and metonymies in the transplantation discourse}

As we said above, the term "transplantation" is itself metaphorical. The organ/body part is metaphorically conceived as a plant, and the human, i.e. the patient corresponds to a garden (PATIENT IS A GARDEN). The verb comes from Late Latin transplantare 'plant again in a different place', from Latin trans- 'across' + plantare 'to plant'. It was extended to people (1550s) and then to organs or tissue (1786), which is now the dominant sense, at least judging by the majority of English dictionaries. Nevertheless, the link between the literal, botanical sense and the medical one is still alive in English and in many other languages that use analogous constructions (e.g. presađivanje organa in Croatian, or szervátültetés in Hungarian).

In addition to these general gardening metaphors, there is a series of conceptual metaphors targeting the transplanted organ that is conceptualized metaphorically as a living organism:

(1) When I feel that my kidney is complaining, I stop working.

(2) It's alive! It throbs. If it does not move, your kidney has a problem... when it needs water, it knocks. (Shimazono 2013)

A transplanted organ, say a kidney, may be specifically conceptualized as a baby, or as a foster child:

(3) Oh yes, it's part of me - it's me, it's me. I even call it my baby.... it's really a special part of me! I felt I must be responsible for this other person's kidney. 
In some cases, the transplanted organ is seen as a spare part, which means that human (body) is metaphorically construed as a machine:

(4) ... heart is a pump.

(5) It actually will be just like cars: Well, gosh, the radiator is broken, or won't live long: out with it, put a new one in.

One of very frequently used metaphors used to talk about organ donation is DONATED ORGAN IS A GIFT, very often elaborated as gift of life.

(6) There are too many healthy organs currently being cremated or buried in the ground when they could be used to give a great gift to someone in need.

(7) Thanks to the generosity of 98 families donating the organs of their loved ones, 308 people received the gift of life through transplant surgery in 2017 and he acknowledges the courage and generosity of families who have donated their loved one's organs.

This metaphor can be realized multimodally, i.e. verbally and visually as well. In Figure 2 below, in addition to the text hand over the gift of life, we also see a hand holding a human heart that is about to be handed to another person whose open hand in the lower part of the picture is ready to receive it. We are going to discuss the role of metonymy in transplantology discourse below in more detail, but let us just briefly note that it is also involved here. We do not of course mean by that the nail varnish visible on some of the fingers of both hands in Figure 2, which metonymically indicates that both the donor and the recipient are females. Rather, we mean heart conventionally standing for love that accompanies the act of giving the gift of life. Interestingly, we have a situation sometimes referred to as syllepsis in rhetoric - the alternation between the basic, non-figurative, and the extended or figurative sense. Heart is a metonymy for love, but at the same time it is literally an organ that is donated.

This same GIFT metaphor is realized purely visually in Figure 3, in which we can see a schematic human figure with a middle part of its body moved forward in front of the body, shown in red, packaged as a gift parcel, complete with a curling ribbon. 


\section{EZIKOSLOVLJE \\ 21.3 (2020): 305-344}

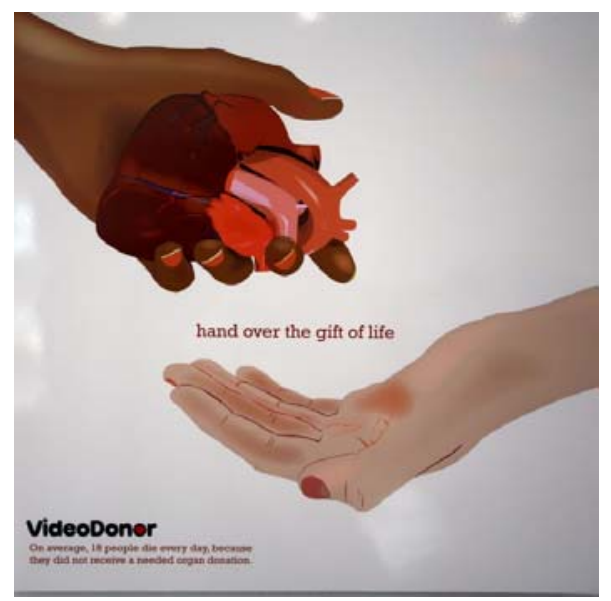

Figure 2. A visual realization of the conceptual metaphor DONATED ORGAN IS A GIFT

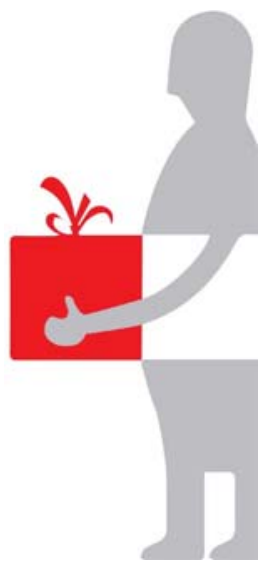

Figure 3. A poster for the Committee of Organ Donation of Lebanon, created by DDB (Doyle, Dane and Bernbach) ${ }^{2}$

We have already seen some examples of metonymies used as terms in transplantology, but generally they are, just like metonymies in general language, far less conspicuous than metaphors. We may as well add some further examples like heart beating donor, skin, or transplant survival rate. The first of these is the label used

\footnotetext{
${ }^{2}$ All the illustrations in this article are taken from various websites that promote organ donation and therefore make these materials freely reproducible for private study or research on the condition that the source is recognised.
} 
(as a euphemistic synonym of heart-beating cadaver) to refer to a donor of an organ who is pronounced dead in all medical and legal respects, but who is connected to a medical ventilator and thus retains cardio-pulmonary functions. Taking the expression heart beating in its literal sense might lead us to wrongly assume that the donor is really alive, as heart beat can be metonymically understood as part of being fully alive. However, in the present context, this is a metonymy that narrows down life to a very limited form, to artificially keeping certain bodily functions with no cerebral activity, which extends the period of time in which body organs can be transplanted to another human. Skin is in the context of transplantation not to be understood as the whole of the soft outer tissue covering of vertebrates, or just a piece of it, but more narrowly as strips of skin in full or partial thickness prepared for grafting. The expression transplant survival rate, which can indeed be used to refer to the percentage of functioning transplants over a given period of time, but is also used to metonymically refer to the survival rate of patients with transplanted organs. Finally, consider the following example:

(8) Competing risk survival analysis was performed to assess gender disparity in waiting list mortality.

In various collocations with the noun mortality where the premodifier denotes a disease, the whole constructions can be interpreted as 'mortality caused by disease $\mathrm{X}$ '. This of course does not work in (8), where the noun mortality can be preceded by expressions such as patient, adult, male, juvenile, etc. The expression waiting list is actually used metonymically to refer to 'people placed on the waiting list'.

Of course, metaphors and metonymies can appear together, as in the following visual example. This is once more the GIFT metaphor, represented again as a parcel with a red ribbon. The ribbon is very long and connects the female figure handing the gift parcel with a number of people in the back on the right hand side. The ribbon is transformed into a curve that looks like an electrocardiogram curve, thus metonymically standing for the heart as the donated organ, but at the same time, the curve represents the heartbeat, and therefore also metonymically stands for life (BEATING HEART FOR LIFE). 


\section{EZIKOSLOVLJE \\ 21.3 (2020): 305-344}

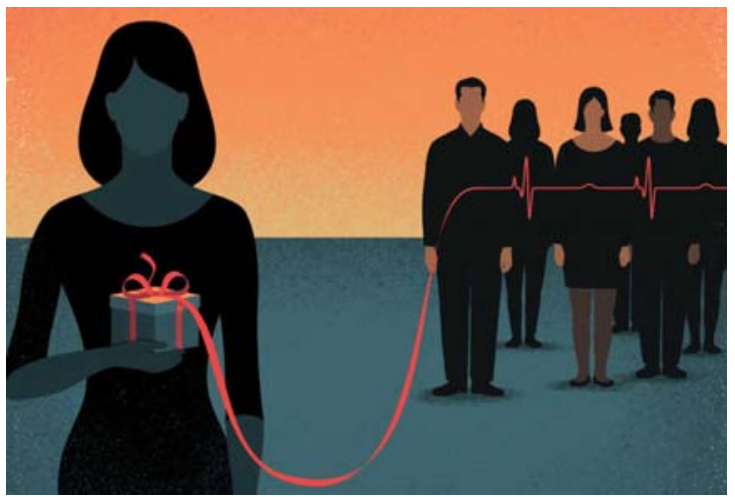

Figure 4 . The interaction of a metaphor and a metonymy ${ }^{3}$

\section{Figurative framing of discourse}

The numbers of patients waiting for an organ transplant, actually receiving a transplant in time, and the numbers of those who died while still on the list that we reported at the very beginning of this article obviously call for an urgent proactive reaction by the institutions in charge of handling the problem in the sense that they must change the public perception towards organ donation and transplantation by any means available to them.

One of these means is certainly metaphor. According to Lakoff and Johnson (1980: 36), metaphor is "principally a way of conceiving of one thing in terms of another, and its primary function is understanding," but they can also "express, reflect, and reinforce different ways of making sense of particular aspects of our lives" (Semino et al. 2018: 625). In other words, metaphors can be used for "framing," and this is also true when they are used in health communication.

We would like to claim here that the phenomenon of framing in general, and in particular in health communication, is not a sort of one-size-fits-all phenomenon, but much more complex, and that it therefore requires a more fine-grained approach. First of all, we would like to point out that framing need not always be achieved solely by means of metaphors, as we show later, metonymy can also play an important role here.

\footnotetext{
${ }^{3}$ Gift of Life Michigan Works to Dispel Myths About Organ Donation - BLAC Detroit Magazine, July 1, 2019. Retrieved from: https://s27380.pcdn.co/wp-content/uploads/2019/07/1216-diaryessay-organ-donation_plnmph.jpg. Accessed: 10 January 2020.
} 
The phenomenon of framing is intriguing as it seems to lead two lives at the same time, though with some overlap. It has one foot in linguistics and the other in sociology, and psychology, but also in journalism and mass communication. The term itself seems to have been originally coined by the sociologist Erving Goffman in his 1974 book. He is primarily concerned with studying ways of social construction of reality. We might as well add that in the present context of transplantology discourse the prime concern is not just to construct reality, but rather re-construct it in a different way, more favourable to the goals of the institutions involved, the whole field, and therefore the society as a whole.

For Entman (1993)

... [t]o frame is to select some aspects of a perceived reality and make them more salient in a communicating text, in such a way as to promote a particular problem definition, causal interpretation, moral evaluation, and/or treatment recommendation,... (1993: 52)

As Hertog and McLeod put it,

Choosing what frame ... phenomena are to be placed in may do more to determine their meaning than lengthy discussions of the facts of or arguments toward them. ... Once an unfamiliar idea, topic, action, or event has been framed its interpretation is driven by the frame. (Hertog \& McLeod 2001: 147)

Kahneman and Tversky's (1979) prospect theory starts from the assumption that people can be persuaded to make different decisions concerning an issue due to different ways of formulating a message about that issue. Specifically, when a message is positive and stresses the benefits that could be accrued or the disadvantages that could be prevented by taking certain actions, it is said to be "gain-framed". On the other hand, when a message is negative and the emphasis is on the disadvantages that could result from taking certain actions or the losses that could be the consequence of not taking other actions, it is said to be a "loss-framed" message.

An important observation by Kahneman and Tversky that will play a central role in Section 4, is that people tend to avoid risks when the consequences of a choice are presented in terms of gains. On the other hand, they are more prone to engage in riskier options when outcomes are expressed in terms of losses. Thus a number of studies showed that disease or accident prevention behaviors that pose a relatively low risk, such as complying with the use of sunblockers or the use of seatbelts, are more effectively encouraged by gain-framed appeals than by loss-framed appeals, and conversely that disease detection behaviors that pose a higher risk of shedding light on unpleasant facts, such as mammography or colon cancer screen- 
ing, are more effectively encouraged by loss-framed appeals than by gain-framed appeals (cf. Broemer 2002; Kuhberger et al. 1999; Lauriola et al. 2005). Loss- vs. gain-framing can be seen as a general, strategic choice in approaching a topic.

Returning to framing in linguistics, we realize that the concept of frame has developed in American linguistics completely independently of the above advances in sociology, as pointed out by Cienki (2009), but it has more recently moved in the direction of coming very close to the concept used in sociology and psychology. It is customary nowadays in cognitive linguistics to see frames as a:

... portion of background knowledge that (i) concerns a particular aspect of the world, (ii) generates expectations and inferences in communication and action, and (iii) tends to be associated with particular lexical and grammatical choices in language. (Semino et al. 2018: 627)

Although the phenomenon of framing has been primarily studied in contexts of wider issues involving whole societies or particular social groups, we are of the opinion that it can be found in all kinds of situations, in all kinds of contexts in which discourse participants interact. Depending on the function of discourse and the participants involved (and their power status), framing effects can be private (e.g. when an organ recipient describes his/her experience to other organ recipients, to health practitioners, or to his/her family), or more institutional (e.g. when a health agency or a health institution presents organ donation and transplantation to general public, particularly with an eye to potential donors. As we said before, these are to be understood as two poles on the continuum. A similar broadening of the scope of the term framing is proposed by Cienki (2009), who uses the label "spoken language framing" to refer to choices made in a canonical encounter (Clark 1973) with speakers meeting face-to-face and engaging in conversation.

Further, we consider that distinguishing between two levels of framing may also be very useful. Framing can be observed at the level of the choice of a metaphor (or a metaphor (sub)system), which we call global framing. The extension (Thibodeau 2016) or explication of metaphors through stating selected mappings (or submetaphors) may also play an important role in making sense of particular aspects of our lives - framing at this level may be considered local framing. These two levels may, but of course need not, correlate with the strategic function and the type of discourse, the number and kind of participants in discourse, and their power roles. 


\section{Framing the transplantation/organ donation discourse by means of metaphors, with a little help from metonymy}

Let us now illustrate how this works in transplantology discourse. Needless to say, we are primarily interested in global/strategic framing taking place in discourse aimed at potential organ donors and transplantees(-to-be). The specific goal of this article is to assess the types of metaphors and metonymies used in this latter case of framing the discourse about organ donation and transplantation, and check how (in)efficient they are, and what can be done to make this type of discourse more persuasive. Putting it informally, we would like to check whether health agencies and institutions "score a goal or an own-goal" (El Refaie 2015) in such cases.

The analysis of the data compiled in the course of work on our project, as well as the data available in literature, indicates that the PLANT and the GARDEN frames are practically never used to frame the issues of organ donation and transplantation. This is so in spite of the intrinsic appeal of the metaphors based on these due to the fact that there is a marked conceptual distance between the source and the target domain and that a rich set of mappings obtains between them, both of which should be favourable to framing, these. This may be in part due to the fact that the metaphors involved have attained the status of medical terms and are no longer $100 \%$ alive, on the one hand, and to the negative connotations of these frames with respect to the quality of life in the sense that they possibly suggest vegetating and not living normally, with possible further negative effects of expressions such as organ harvesting, on the other.

The analysis of the one-to-one interactions in interviews shows that transplantees(to-be) often make use of mechanistic metaphors (HUMANS ARE MACHINES). In other words, at the private end of the continuum they locally frame transplanted organs or themselves as machines or as their parts. This sort of framing takes place at two levels, as their frames are elaborated in the majority of cases by means of explicitly spelling out mappings, as can be seen in the following examples from Schweda and Schicktanz (2009: 5):

(9) So, one should probably not have an altogether negative attitude towards this [an overall replacement of organs]. Since it can easily become, as we said, like science fiction, let us replace this, let us replace ... that. Just like when you take your car to the garage, it is coughing and such, yes, let us replace that and fix that and then you are off again.

(10) I've been hanging to give my new lungs a real test drive, since I arrived here. So, today I'm off to the closest shopping mall. 
(11) I had an argument with my physician: I want 'Mercedes'-lungs, or else I want to die. I mean it, I really said it like this. I have got 'Mercedes'lungs, I don't want a 'Lada'.

Examples like (11) are not pure metaphors, or at least, one figurative conceptual layer is not metaphorical but metonymic. This becomes more evident when we realize the relevance of contrasting two car types - (11) is a comment on the quality of the donated lungs, and not so much stressing their machine-like being. Mercedes and Lada are in this example used as paragons. According to Lakoff (1987: 87), a paragon is an individual member or a set of individual members of a category "who represent either an ideal or its opposite". Needless to say, paragons can be based not only on humans, but also on organizations and inanimate objects. A paragon model is essentially metonymic (just like stereotypes, etc.), as an ideal member of a category stands for the whole category. Barcelona (2003; 2004: 364) improves on Lakoff's analysis as he demonstrates that the model is based on two metonymies, first the name of the bearer of a given outstanding property comes to stand for the property in question, which is followed by the ideal member of a category for the whole category. Thus, the paragon Shakespeare stands for the class of writers that have an immense literary talent. As a result, Shakespeare becomes a class name and is in part coded as a common noun as far as its grammatical behaviour is concerned. As pointed out in Brdar and Brdar-Szabó (2007), the axiological notions "best of" and "worst of" as the most problematical in the paragon model arise in another metonymic tier due to the imposition of a scalar model (Israel 1997; 1998) on these contrastive properties. The scalar model allows the metonymic mappings of the type whole scale for upper/lower end of scale (cf. Kövecses \& Radden 1998: 51 ), whereby the property is interpreted as being exhibited to the maximum, either in the positive or negative sense.

Closer to the middle part of our continuum, when donors and/or transplantees talk about their experience in Internet forums, we find a range of conceptual metaphors, from TRANSPLANTED ORGAN IS A LIVING ORGANISM to TRANSPLANTATION IS A MIRACLE, to the standard TRANSPLANTED ORGAN IS A GIFT, most of which we have already encountered above.

(12) Mike received what he calls, "The most fun-loving and energetic right lobe of a liver that has ever been transplanted."

(13) A heart transplant is a miracle

It took almost two years for the miracle to happen.

(14) Tammy's sacrifice, her gift, made it possible. 
(15) Someone had given me his heart so that I could have a better quality of life. I truly believe that God was reflected in the love I received from my family, friends and doctors. I felt a necessity to give back a little bit of what was given to me.

(16) There are no words to express the tremendous gratitude that I carry as the result of my donor's selfless gift.

The gift metaphor is occasionally reinforced by a metonymy of the PART FOR WHOLE type in which an activity is singled out as indicating the patient's quality of life after the transplantation.

(17) I was told by my rehabilitation team that I would likely not walk again. Being just 19 years old, I found this unacceptable. I have had a passion for riding horses and was determined to get back in the saddle. ...

I walked on the treadmill and used the machines even though it was always quite an ordeal. It took time; I can now say that I proved the doctors wrong. I am now riding horses again and taking a full load of courses. $\cdots$

Words can't begin to describe how grateful I am for my donor and their family for giving me the ultimate gift.

A metonymy of this type can also appear on its own:

(18) September 14, 2011 is the day I refer to as "the day I got my smile back." On that day, I underwent brain surgery to help alleviate symptoms of a Chiari Malformation, which occurs when the cerebellum (at the back part of the brain) slips from the skull and into the spinal column.

My surgery was incredibly successful and it was ever more life-changing than I first realized because donor tissue was used in the area surrounding my brain, allowing me to be nearly symptom free. I am now a tissue recipient!

The picture of organ donation and transplantation in mass media, roughly occupying the middle section of the continuum between the private and the institutional, is of course different. Here we find several types of conceptual metaphors that help frame the whole issue towards criticism or support. There are mechanistic metaphors, metaphors presenting humans as buildings, and organ donation as recycling, etc.: 
(19) Spare-part surgery is moving closer to reality, according to a pioneer kidney-transplant surgeon, Professor Sir Michael Woodruff. Replacement surgery covers the transplanting of organs and limbs from dead people to those in need of spare parts.

(20) An internationally famous cardiologist has suggested that heart transplants are the work of "plumber surgeons" and that research into the prevention of vascular disease is much more important.

Moloney and Walker (2000) conducted a frame analysis of organ donation in print news in Australia, discovering a number of conceptual metaphors (although they do not actually mention metaphors, but just frames). Surgeons may be presented as VULTURES or as MESSIAHS.

(14) Dr Geoffrey Spencer, head of the intensive care unit at London's St Thomas Hospital, said yesterday that transplant surgeons were a gang of vultures. "They hang around the body waiting to snatch out organs, starting with the cornea and ranging to the heart," he said.

Professor Chris Barnard, who performed the first heart transplantation in 1967, is reported as being addressed by his patient in the following way:

(15) He said to the surgeon, Professor Chris Barnard, who stood by his bedside: "What kind of operation did I have? You promised me a new heart." "You have a new heart," the surgeon told him.

This strongly resembles the way that Jesus talked to sick people who were healed by him. This idea is reinforced by Professor Barnard's own words in which he actually turns the metaphor in question inside out:

(16) Adam was the donor, God the surgeon and He made Eve out of Adam's rib.

Even further towards the institutional end of the continuum we find a sort of discourse produced by health practitioners that is intended to inform patients and/or potential organ donors. It is very similar to the above in terms of its choice of central metaphors that shape these utterances. There are again TRANSPLANTED ORGAN IS A LIVING ORGANISM (because the verb outlive is in its literal sense primarily used to establish a relation between two living organisms, one of which lives longer than the other) and TRANSPLANTED ORGAN IS A GIFT metaphors, but also ORGAN FOR TRANSPLANTATION IS A COMMODITY that can be exchanged or swapped, as in (26):

(24) A very young kidney recipient, for example, may outlive their organ. 
(25) Keith (right) received the GIFT OF LIFE when he was given a kidney from his stepson Jonny (left).

(26) "Swaps" or exchanges match two (or more) of these would-be donors with each other's intended recipient. Exchanges can involve two sets of donors and recipients or a group of several donor and recipient pairs, sometimes at multiple hospitals across the country.

On the other hand, discourse types at the very end of the continuum, i.e. at the institutional pole, produced by hospitals or organizations in charge of organizing and managing processes involved in organ transplantation and aimed at wider audience, i.e. at prospective organ donors, and patients who have undergone or are about to undergo organ transplantation, appear to rely almost exclusively on the gain-framing by means of the GIFT metaphor (Thompson 2003), accompanied by the idea of new life made possible by the gift, as shown in examples (27) and in Figures 5 and 6 below.

(27) 25 Years Post-Transplant, Still Grateful for Gift of Life

Type 1 Diabetes nearly killed Faith Carlin until she received the gift of a kidney and pancreas transplant that saved her life.

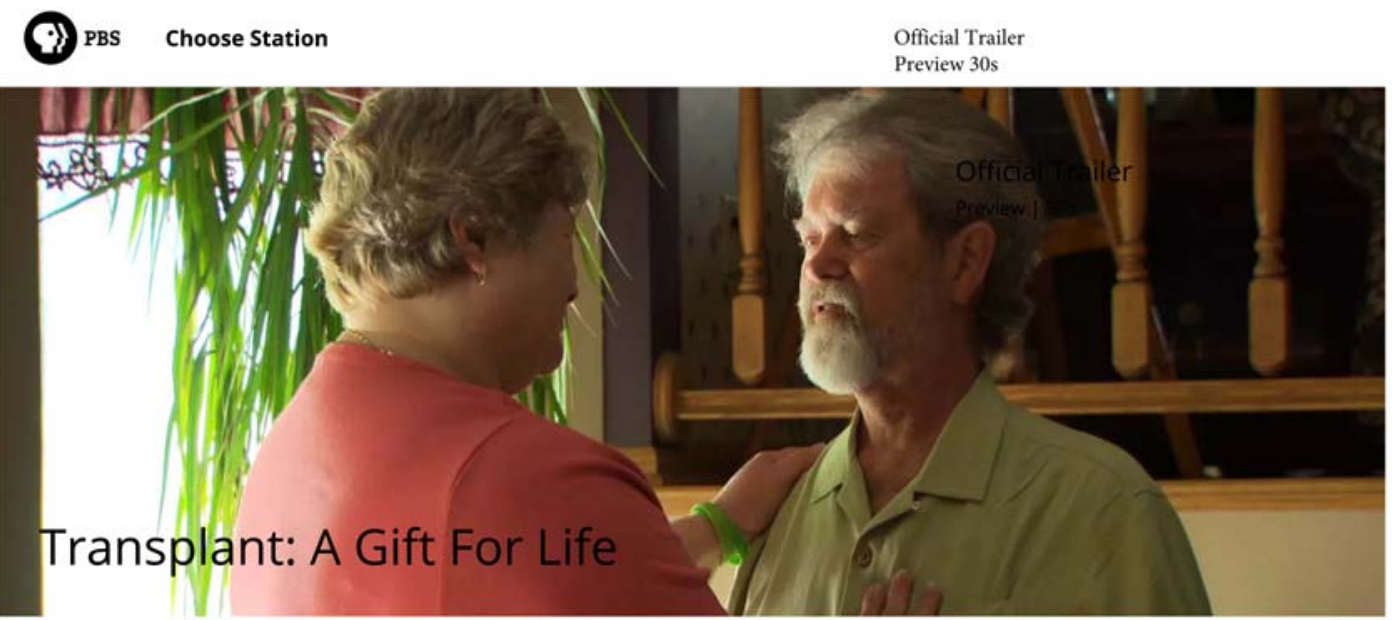

Figure 5. A screenshot from the documentary by Public Radio North Carolina ${ }^{4}$

\footnotetext{
${ }^{4}$ Retrieved from: https://video.unctv.org/show/transplant-gift-life-tpt/. Accessed: 28 May 2019.
} 


\section{EZIKOSLOVLJE \\ 21.3 (2020): 305-344}

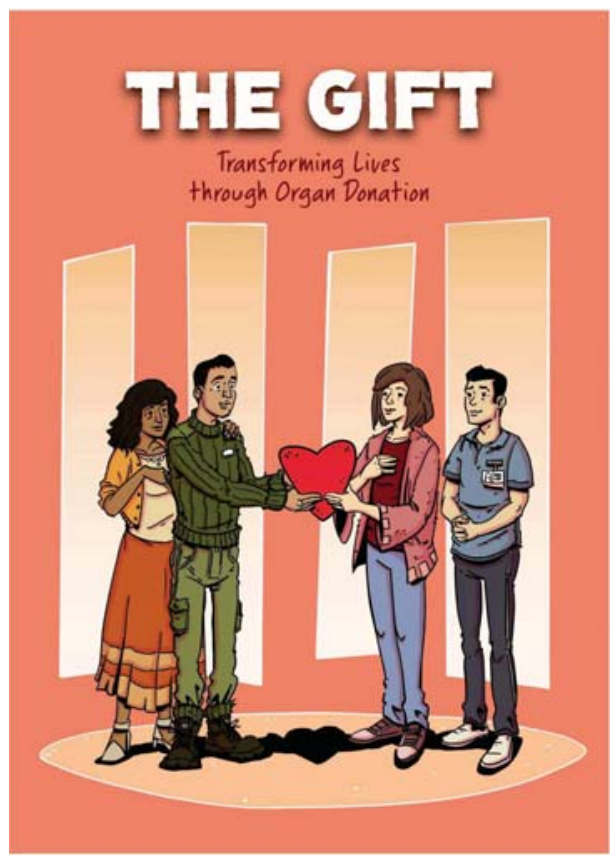

Figure 6. The title page of the graphic novel The Gift

The metaphor in question is hardly elaborated in any way in the sense of Thibodeau (2016) and does not seem to be very persuasive. They are felt to be quite general and too abstract while playing on the altruism card. However, we should bear in mind the qualitative data we cited at the very beginning of this article that show the gap between the number of prospective and actual organ and tissue donors and the number of patients on the waiting lists (as well as the number of patients who die while on the list).

In order to understand what is going on here and why most of these campaigns are not as successful as they should or might have been, we should consider the observed facts in light of a combination of Kahneman and Tversky's prospect theory and the exemplification theory (often described as a theory of media influence) by Zillmann (1999; 2002) and Zillmann and Brosius (2000). For the time being, let us just say that this theory suggests that if something is portrayed in a vivid, emotion-

${ }^{5}$ Crowe, M., Murray, C., Nabizadeh, G., Findlay, L., Vaughan, P., Herd, D., Crowe, S. (2018). The Gift: Transforming Lives through Organ Donation. (1 ed.) Dundee. Retrieved from: https://discovery.dundee.ac.uk/en/publications/the-gift-transforming-lives-through-organ-donation. Accessed: 3 October 2019. 
al, and concrete way it will tend to have stronger perceptual influence than something that contains more general descriptions and statistical information. As pointed out by Zillmann (1999: 70), people give "disproportional attention to concrete, often vividly displayed events ... and ... this attentional preference comes at the expense of attention to more abstract, comparatively pallidly presented information".

One might intuitively expect that gain-framing and altruistic motivation should be very effective when trying to persuade someone to donate organs. However, Humphries et al. (2009) suggest that altruism is significantly related to donor motivation only for donations to immediate family members. Some studies examining the differing effects of gain- and loss-framed arguments on intentions toward organ donation indicate that the former may be more effective than the latter. Reinhart et al. (2007) found that students reading a gain-framed message exhibited significantly more favorable reactions to the issue of organ donation and lower levels of psychological resistance than did students who read a loss-framed message. Purewal and van den Akker (2010) found that gain-framed messages significantly increased the intentions of British women to donate egg cells compared with loss-framed messages, but no significant difference was observed with regard to the effect of message framing on egg cell donation intentions among Southeast Asian women. However, on closer inspection it turns out that these two studies reported an effect size of $r=.20$ and .12, respectively, the former correlation coefficient actually falling between medium and small effect size, the latter being very close to the threshold for small effect sizes.

Although there might be differences concerning the risk involved in donating an organ (e.g. McGregor et al. 2011 showed that willingness to donate was significantly higher when the risk of donating was lower, as in the case of kidney donation, than in the case of liver donation, which is riskier), we can generally say that donating an organ as a live donor, and even after one's death, is an action linked with a relatively high risk, for a number of reasons we need not go into here. As we have seen before, the prospect theory predicts that people will tend to prefer to take a gamble over certainty when information is presented as losses, whereas they will avoid risks when presented with gains. This leads us to a somewhat surprising but logical assumption that one of the reasons that campaigns directed at prospective organ donors are less effective than one would desire is that we have an obvious incongruence between a relatively high risk involved and the gain-framing of the contents in most of these stories based on the idea of the gift of life. Metaphorically speaking, the carrot of the gain-frame does not work well with a high risk. 
That gain-framing is not the best possible strategy when coupled with high risk in the context of organ donation has been demonstrated by several studies. Sallis et al. (2018) study the effect of seven types of persuasive messages on prompting British drivers to join the National Health Service Organ Donation Register. The two most effective types of message turned out to be the one playing on reciprocity (the fact that the subject might find one day himself/herself in the position of applying for organ transplantation) and the one that was loss-framed, roughly producing the same reactions, the gain-framed message being somewhere in the middle. Another study, conducted in 2013 by Behavioural Insights Team, ${ }^{6}$ showed the same inclination: subjects were more likely to sign up for the register after being exposed to a webpage promoting reciprocity, closely followed by the loss-framed webpage, the gain-framed webpage performing less well again.

Sallis et al. (2018: 7) point out that the reciprocity may be perhaps attributed to anticipated guilt on the part of subjects, but we think that reciprocity is the result of blending the situation associated with the loss-frame with the current reality situation of the subject, i.e. it is created by the subject projecting himself or herself into an imaginary situation in which he or she is ill and in need of a transplant, and possibly by conversely projecting the person in need of a transplant at the present moment into a world in which this person is healthy and is a potential donor. So it is essentially a loss-frame strengthened by an example that is as close to the subject as possible.

Of course, not all campaigns are based on the gain-frame. Jaslok Hospital in Mumbai launched an Instagram campaign in 2018 trying to encourage Indians to pledge their organs (see Figure 16 below). It features a text that stresses the loss: 500,000 people die every year due to inavailabilty of organs in India. By liking this Instagram entry readers would attempt to neutralize the loss-framing, i.e. the bad feelings due to the guilt are countered by a feel-good action such as liking, as the reader feels that he or she has done something. However, the ingeniously designed campaign features six posts that immediately unlike any likes they might receive, clearly showing that a slacktivist response of expressing sympathy is not enough. In fact, we could say that this campaign transcends simple loss-framing by transforming itself to a challenge. As this unliking is not made public for everyone to see (and this is why the challenge does not become a face-threat), in contrast to the Instagram campaign itself, we could say that we have a hybrid form here that starts

6 Retrieved from: https://www.bi.team/publications/applying-behavioural-insights-to-organdonation/. Accessed: 3 October 2019. 
at the institutional/public end of our continuum, but then reverts to the individual pole.

As we have seen above, the exemplification theory suggests that qualitative evidence focused on particular exemplar characters in the form of personal anecdotes, analogies, examples, stories, and testimony is much more persuasive than quantitative evidence regarding that same behavior (Brosius \& Bathelt 1994) as it makes it possible for people to align themselves with others of their kind. The study by Kazoleas (1993) suggests that people might be less critical of exemplar. In another study, Studts et al. (2010) studied the relationship between marrow donation and statistical versus exemplar messages. They concluded that exemplar messages significantly increased medical students' intentions to register with the National Marrow Donor Program when compared with statistical messages. What is more, Chien and Chang (2015) found that loss-exemplar messages elicited significantly more positive intentions toward donation than did loss-statistical messages, while there was no significant difference between the statistical and exemplar appeals observed under the gain-framed condition.

In the remaining part of this analysis we would like to demonstrate the role of metonymy in creating the exemplification effect, which strengthens the loss-frame, and may make gain-framed narratives more acceptable/successful, or even viable as a stand-alone strategy in building the narrative. We might start by comparing two brochures used by hospitals to prepare juvenile patients for the transplantation surgery. One is in Hungarian, authored by Erika Bartos, and titled Új élet, új mosoly (New life, new smile), ${ }^{7}$ the other is in English, titled Mommy Can Play Again. ${ }^{8}$

\footnotetext{
${ }^{7}$ Bartos, Erika. 2016. Új élet. Mesekönyv a vesebetegségröl és a szervátültetésröl. Budapest: Tappancs Egyesület.

8 Transplant Recipients International Organization (TRIO). 2012. Mommy Can Play Again. A story for children of families facing transplant - based on a real-life story as illustrated by transplant family children. Philadelphia: Philadelphia TRIO. (Retrieved from: https://www.trioweb. org/images/ files/ resources/downloads/MommyCanPlayAgain\%20final.pdf. Accessed: 3 April 2017).
} 


\section{EZIKOSLOVLJE \\ 21.3 (2020): 305-344}

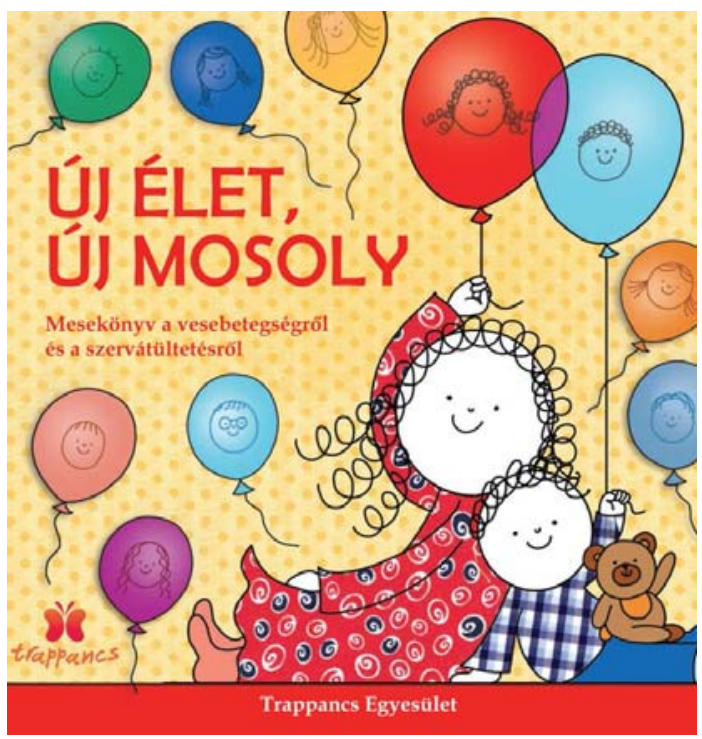

Figure 7. The cover of the Új élet, új mosoly (New life, new smile)

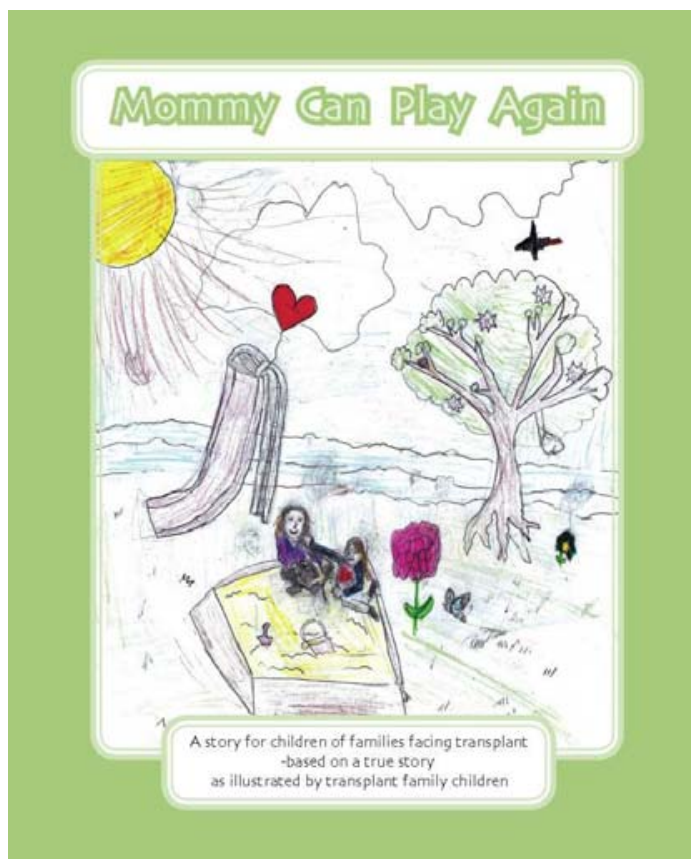

Figure 8. The cover of Mommy Can Play Again 
The Hungarian booklet is about a small boy whose kidneys are not working properly and who gets a new kidney from a donor, while the English-language booklet is about a small girl's mother, who needs new lungs. Apart from this, the most conspicuous difference between the two is that the Hungarian one is almost entirely based on conceptual metaphors, while the English one is significantly relying on conceptual metonymies, too. There are metonymies in the Hungarian book as well (e.g. the new smile could be seen as a metonymy, standing for a new life without health problems), but metaphors dominate, from the personification of nephrons, blood cells, minerals, and microbes (e.g. the presentation of a kidney in Figure 9 below) to the central metaphor of new life as a gift, i.e. as THE TRANSPLANTED ORGAN IS A GIFT.

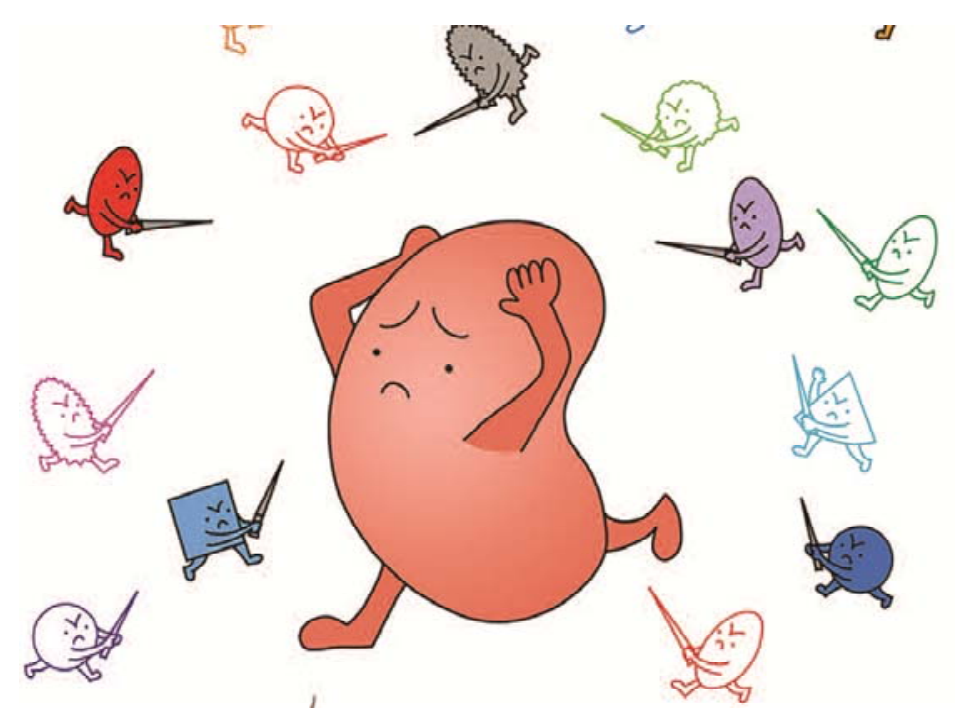

Figure 9. Personification of the kidney in the picture book by Bartos

On the other hand, the English-language booklet is systematically built around the central metonymy of play that stands for life unconstrained with a disease. The story of the booklet opens on page 7 as follows: 


\section{EZIKOSLOVLJE \\ 21.3 (2020): 305-344}

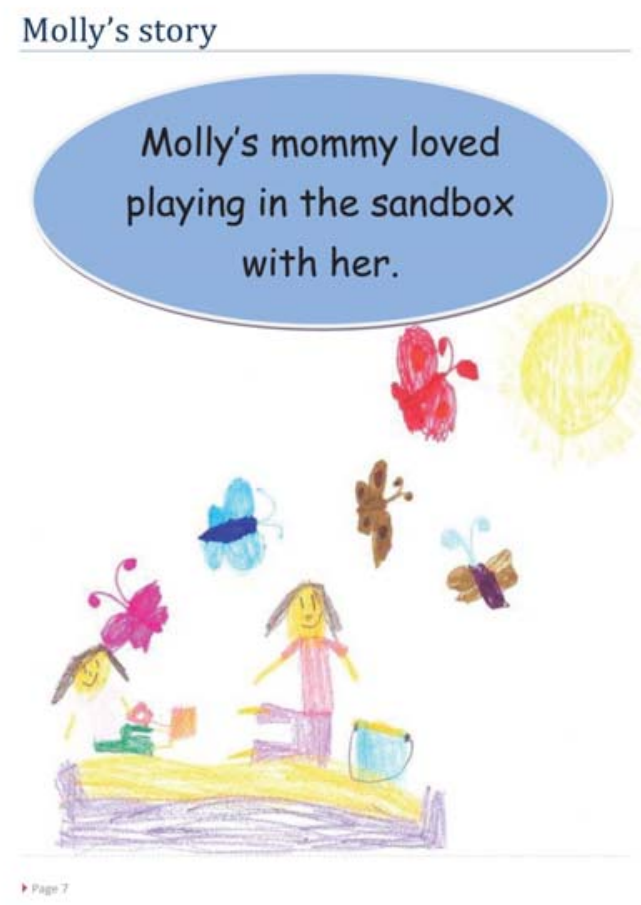

Figure 10. The beginning of Mommy Can Play Again

Next two pages ( 8 and 9) introduce the problem, while pages 12 and 13 communicate the solution. Mother's illness is announced metonymically through its symptoms, without going into the details of a diagnosis that a child cannot understand (Figure 11). The booklet also personifies the lungs (Figure 12), just like the Hungarian booklet did with the kidney. It also conceptualizes the new organ as a gift, just like the Hungarian booklet. In a sort of euphemistic move, the picture on page 24 (reproduced here as Figure 13) visualizes the source domain, and not the (real) target domain. All we see is a nicely packaged box with a tag attached to it saying: Here are your new lungs. Enjoy!, just the way it is done with ordinary gifts. 
Mario Brdar - Rita Brdar-Szabó:

The role of metaphors and metonymies in framing the transplantation discourse

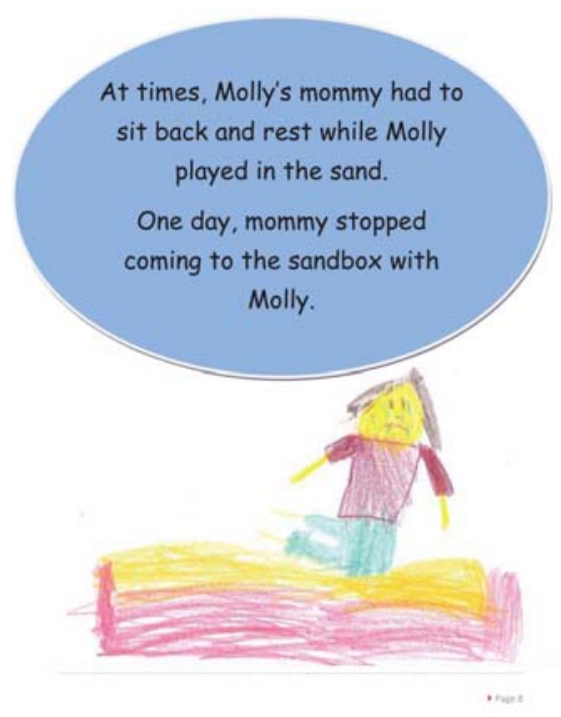

Figure 11. The description of illness based on metonymy in Mommy Can Play Again

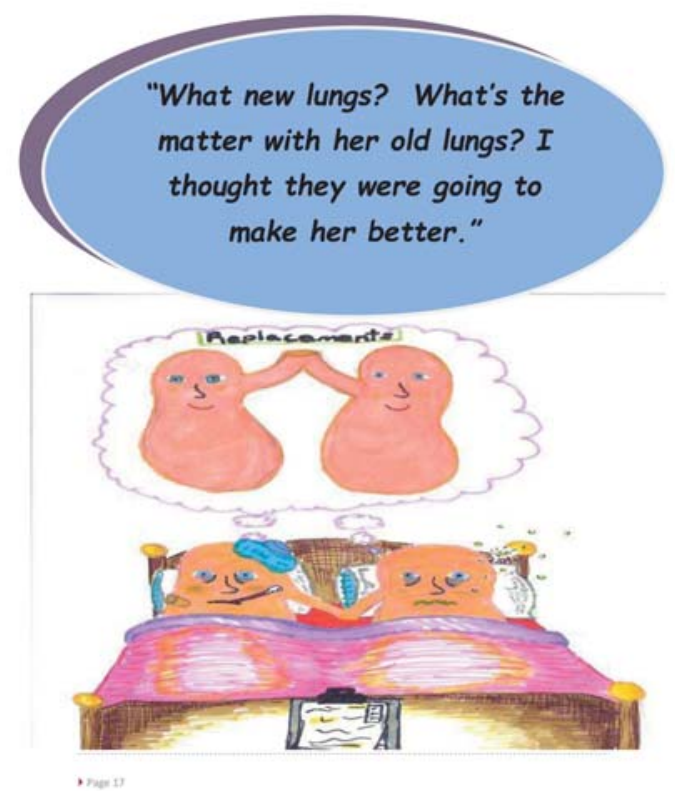

Figure 12. The personification of lungs in Mommy Can Play Again 


\section{EZIKOSLOVLJE \\ 21.3 (2020): 305-344}

It was hard for Molly to wait,

but one day her mommy went

into the hospital to get her

gift of new lungs.

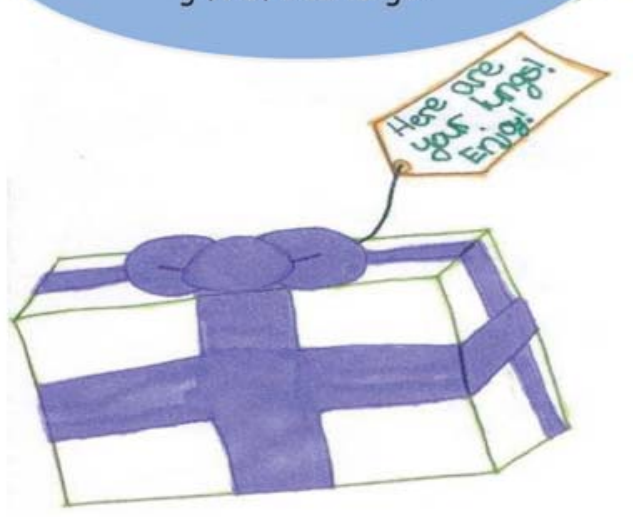

Figure 13. Transplanted organ as a gift in Mommy Can Play Again

However, metonymies dominate in the booklet. The booklet closes with the same play metonymy. The caption under the picture says: Now Molly can play with her mommy in the sandbox as before, just like she always wanted.

The use of this variety of metonymies seems to be more appropriate than just the use of the GIFT metaphor in order to prepare juvenile patients of family members for the transplantation. Metonymies are here more immediate than rather abstract metaphors, and are therefore easier to process for children. Due to their concreteness, they bring closer the situation that the family has to cope with. This is in perfect sync with advice in the brochure How to talk about organ donation with children by Eileen Hayes (http://orgamites.com/wp-content/themes/orgamites/pdfs/ Orgamites_Parenting_Download.pdf): 


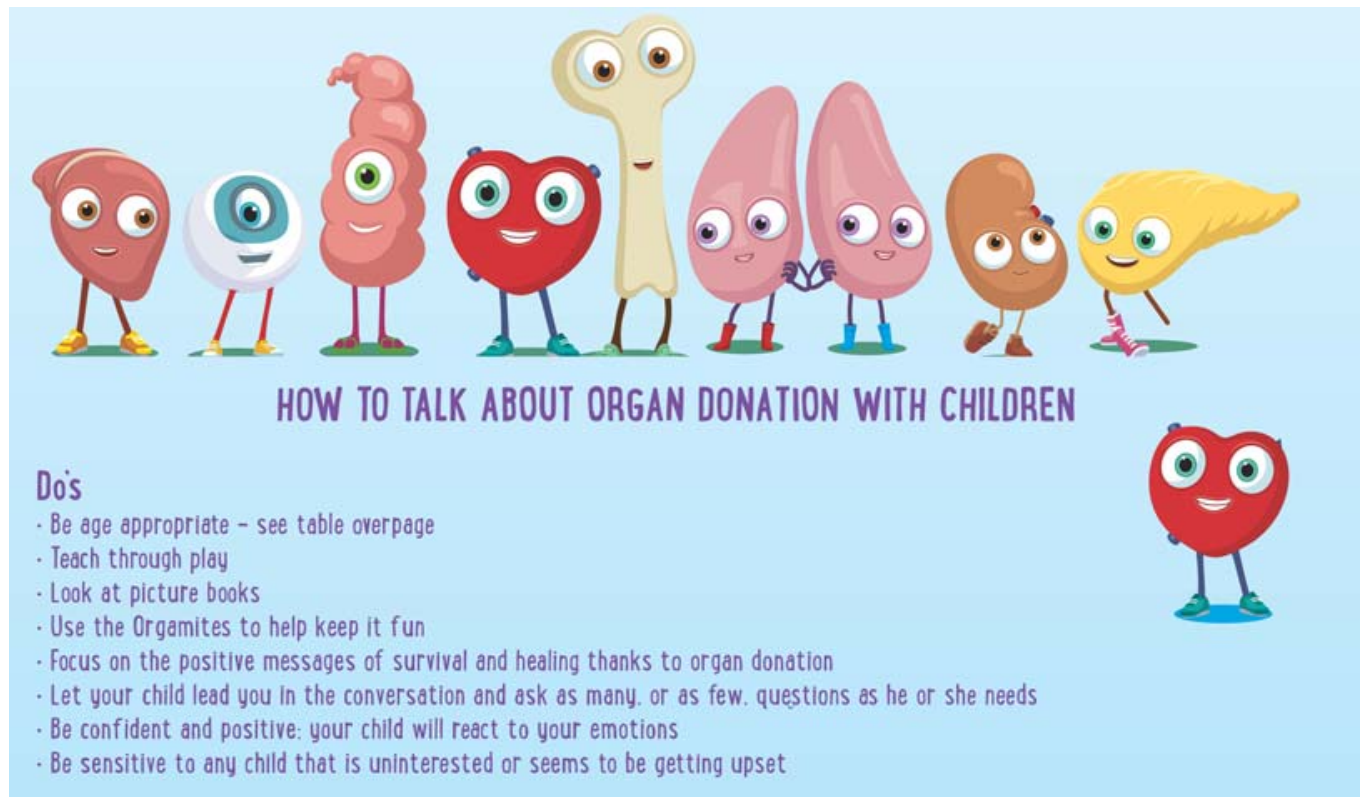

Figure 14. A section from How to talk about organ donation with children by Eileen Hayes ${ }^{9}$

We saw the title page of a graphic novel in Figure 7 above. As indicated by its very title, it is also based on the GIFT metaphor, and is therefore gain-framed. The central part of the novel tells the story of a transplantee, from the beginning of the disease, ending with kidney failure and dialysis, through contemplating organ transplantation. Just before she and her family start thinking about transplantation, a half of page 16 shows her in a bad mood, struggling at her workplace, even with basic daily functions like eating, and spending a lot of time resting in bed or in an armchair. All these details metonymically exemplify the advance of her disease and the deterioration of the quality of her life. A year or so after a successful operation she resumed most of her old activities, and four pages later in the novel, 16 years after the transplant, she realizes how her life has changed for the better. She states that "[t]hings have really changed since the transplant, I do more exercises now, I have: been on holiday, I have boundless energy for my age!" All this is illustrated in the four smaller pictures inset in the central frame on that page as well in the main frame. All the four small pictures and the main frame are metonymic illustrations of salient improvement of the quality of her life after the operation. One pic-

\footnotetext{
${ }^{9}$ Retrieved from: http://orgamites.com/wpcontent/themes/orgamites/pdfs/Orgamites_Parenting_Download.pdf. Accessed: 22 September 2019.
} 


\section{EZIKOSLOVLJE \\ 21.3 (2020): 305-344}

ture shows a table full of all kinds of food and drinks that she can now enjoy. Another small picture features a passport, a ticket and sunglasses, indicating that she can travel abroad. The remaining two pictures are further elaborations of this, one shows a silhouette of a female, probably the main character, standing on the shore of a lake or sea, probably at the sunset, while the last one shows an aeroplane in the air. Below these four small pictures we see the main character jogging in a park.

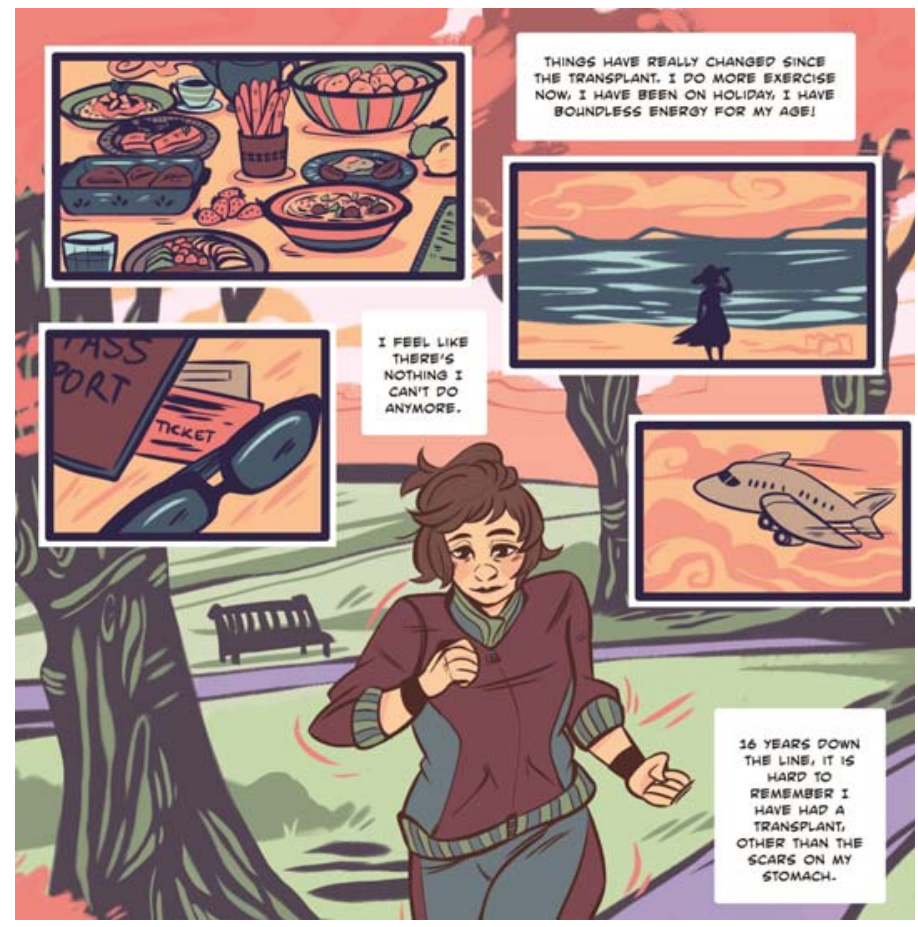

Figure 15. A page from Crowe et al. (2018: 20)

The gain-framing of the whole novel by the gift novel is thus matched and strengthened by metonymies that exemplify what the main character has (re-) gained in her life after the operation.

The Indian Instagram campaign that we mentioned above is an instance of lossframing (recall the textual message: 500,000 people die every year due to inavailabilty of organs in India) that matches the relatively high risk event that is its tenor, i.e. the donation of organs and tissue. At the same time we note that it also agrees with the figurative tools employed. In the centre of the picture below we see an image that is the stylized geographical map of India (we could claim that the represen- 
tation metonymically stands for the entity represented, i.e. the map for the country. In the next layer of metonymic shift, the country stands for its inhabitants, and then finally the entire population of the country stands for potential organ and tissue donors. This series of metonymies prepares the ground for a very general metaphor that is not frequently used in this context, i.e. LESS IS DOWN (which is in consonance with the textual loss-framing). The visual metaphor is indicated by a number of contours produced by bars of different colour inside the image of India. As we progress towards the centre, the colours become darker, and the net result is the visual impression of negative relief, the contours inset into each other produce a feeling of depth. At the same time, the country is shrinking as its image is receding into the depth, i.e. becoming smaller as it goes down (this is why we can say that the metaphor involved is LESS IS DOWN). We apparently have a sort of mix of iconicity and indexicality relationship obtaining between the size of the country and the number of potential donors. As we stated earlier, the designers of the campaign made it impossible to neutralize the loss-framing by any liking of the post.

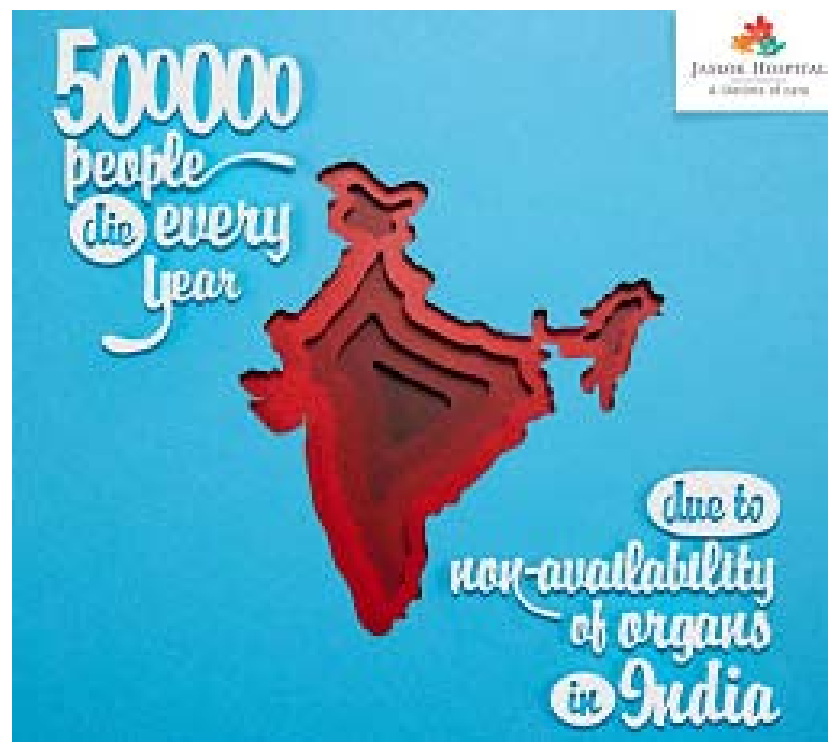

Figure 16. The interplay of metonymy and metaphor in the Instagram campaign for Joslak Hospital ${ }^{10}$

10 Retrieved from: https://www.mumbrella.asia/2018/08/mc-saatchi-returns-to-hong-kong-withoperation-spear-headed-by-spencer-wong. Accessed: 22 October 2019. 


\section{EZIKOSLOVLJE \\ 21.3 (2020): 305-344}

\section{Conclusions}

We have shown that figurative language in transplantology has a number of functions. First of all, both metaphors and metonymies can be used as part of medical terminology, where they can be more or less conventionalized. In addition to this terminological function, both conceptual metaphor and metonymy can have a metacommunicative function in medical discourse as they can help forge closer links between health practitioners and patients, i.e. establish a closer rapport between them. Figurative expressions can also be used euphemistically to cover-up some unpleasant facts. Figurative language can, however, have another important metacommunicative function as it can be used to frame discourse in a particular way, and this is also true of various subtypes of medical discourse.

Assuming that the phenomenon of framing in general, and in particular in health communication, is not a sort of one-size-fits-all phenomenon, but a much more complex one, we have argued for a more fine-grained approach. We also argued that framing need not always be achieved solely by means of metaphors, and that metonymy can also play an important role here.

Further, we have assumed a somewhat wider view of framing than is usually found in the literature and argued that framing effects can be observed on a cline stretching from the private to the institutional pole. Depending on the function of discourse and the participants involved (and their power status), framing effects can be private (e.g. when an organ recipient describes his/her experience to other organ recipients, to health practitioners, or to his/her family), or more institutional (e.g. when a health agency or a health institution presents organ donation and transplantation to general public, particularly with an eye to potential donors). We have combined this approach with the findings of the prospect theory that distinguishes between gain-framing and loss-framing as two strategic choices in tackling an issue in discourse.

When it comes to its realization in discourse, framing can be observed at the level of the choice of a metaphor (or a metaphor (sub)system), which we may call global framing. The extension or explication of metaphors through stating selected mappings (or submetaphors) may also play an important role in making sense of particular aspects of our lives - framing at this level may be considered local framing. These two levels may, but of course need not, correlate with the strategic function and the type of discourse, the number and kind of participants in discourse and their power roles.

The framing tools used in public campaign aimed at winning new organ donors 
are strategically mostly gain-framed, as we demonstrated in our analysis of authentic materials, and as a rule globally based on the GIFT metaphor. It seems that the metaphorical use of GIFT as a global choice in institutional contexts is not very efficient since it is too general and vague to be extended to make discourse more persuasive at the personal level, as expected in the light of the exemplification theory. This metaphor is more effective when adapted accordingly, as we demonstrated on some campaigns in which it was supported by or based on metonymic presentation of various aspects that stress the quality of life after the transplantation (as effects standing for the cause).

Let us point out at the very end, as a word of caution, that we do not argue that metonymies are more effective in framing than metaphors. First of all, we have not claimed that (and therefore we have not empirically tested this issue). What we have claimed is that metaphors as framing devices should and can be adapted as required by the context, and that metonymies can serve as a corrective device to achieve that. They are naturally suited for that in the light of the exemplification theory and of the general differences between metaphors and metonymies, as outlined in Section 2.1. above, the latter typically exhibiting smaller conceptual distance between their source and target concepts.

\section{References}

Barcelona, Antonio. 2000a. Introduction. The cognitive theory of metaphor and metonymy. In Barcelona, Antonio (ed.), Metaphor and metonymy at the crossroads. A cognitive perspective, 1-28. Berlin: Mouton de Gruyter.

Barcelona, Antonio. 2000b. On the plausibility of claiming a metonymic motivation for conceptual metaphor. In Barcelona, Antonio (ed.), Metaphor and metonymy at the crossroads. A cognitive perspective, 31-58. Berlin: Mouton de Gruyter.

Barcelona, Antonio. 2003. Names: A metonymic "return ticket" in five languages. Jezikoslovlje 4. 11-41.

Barcelona, Antonio. 2004. Metonymy behind grammar: The motivation of the seemingly “irregular" grammatical behavior of English paragon names. In Radden, Günter \& Panther, Klaus-Uwe (eds.), Studies in linguistic motivation, 321-355. Berlin: Mouton de Gruyter.

Berber Sardinha, Tony. 2008. Metaphor probabilities in corpora. In Zanotto, Mara Sophia \& Cameron, Lynne \& Cavalcanti, Marilda C. (eds.), Confronting metaphor in use: An applied linguistic approach, 127-147. Amsterdam: John Benjamins. https://doi.org/10.1075/pbns.173.09ber 


\section{EZIKOSLOVLE \\ 21.3 (2020): 305-344}

Berber Sardinha, Tony. 2012. An assessment of metaphor retrieval methods In MacArthur, Fiona \& Oncins-Martínez, José Luis \& Sánchez-García, Manuel \& Piquer Píriz, Ana María (eds.), Metaphor in use: Context, culture, and communication, 21-50. Amsterdam: John Benjamins.

Brdar, Mario. 2007. How to do a couple of things with metonymy. In Cap, Piotr \& Nijakowska, Joanna (eds.), Current trends in pragmatics, 2-32. Newcastle: Cambridge Scholars Publishing.

Brdar, Mario \& Brdar-Szabó, Rita. 2004. On metonymic profiling in alternate construal of complex event chains in verbal idioms. In Lewandowska-Tomaszczyk, Barbara \& Kwiatkowska, Alina (eds.), Imagery in language. Festschrift in honour of Professor Ronald W. Langacker, 247-258. Frankfurt am Main: Peter Lang.

Brdar, Mario \& Brdar-Szabó, Rita. 2007. When Zidane is not simply Zidane, and Bill Gates is not just Bill Gates: Or, Some thoughts on online construction of metaphtonymic meanings of proper names. In Radden, Günter \& Köpcke, \& Klaus-Michael \& Berg, Thomas \& Siemund, Peter (eds.), Aspects of meaning construction, 125-142. Amsterdam: John Benjamins. https://doi.org/10.1075/z.136.09brd

Brdar-Szabó, Rita \& Brdar, Mario. 2012. The problem of data in the cognitive linguistic research on metonymy: a cross-linguistic perspective. Language Sciences 34(6). 728745. doi:10.1016/j.langsci.2012.04.012

Brdar, Mario \& Brdar-Szabó, Rita \& Perak, Benedikt. 2020. Separating (non-)figurative weeds from wheat. In Baicchi, Annalisa (ed.), Figurative meaning construction in thought and language, 46-70. Amsterdam: John Benjamins.

https://doi.org/10.1075/ft1.9.02brd

Broemer, Philip. 2002. Relative effectiveness of differently framed messages: The influence of ambivalence. European Journal of Social Psychology 32. 658-703. https://doi.org/10.1002/ejsp.116

Brosius, Hans-Bernd \& Bathelt, Anke. 1994. The utility of exemplars in persuasive communications. Communication Research 21(1). 48-78. https://doi.10.1177/0093650940210 01004

Broyard, Anatole. 1992. Intoxicated by my illness and other writings on life and death. New York: Ballantine Books.

Chien, Yu-Hung \& Chang, Wen-Te. 2015. Effects of message framing and exemplars on promoting organ donation. Psychological Reports: Employment Psychology \& Marketing 117(3). 692-702. https://doi.10.2466/01.PR0.117c25z7

Cienki, Alan. 2009. Spoken language framing in political discourse. Paper presented at the ECPR Joint Sessions, Lisbon, April 2009.

Clark, Herbert. 1973. Space, time, semantics, and the child. In Moore, Timothy E. (ed.), Cognitive development and the acquisition of language, 27-63. New York: Academic Press.

Crespo Fernández, Eliecer. 2006. The language of death: Euphemism and conceptual met- 
aphorization in Victorian obituaries. SKY Journal of Linguistics 19. 101-130.

El Refaie, Elisabeth. 2015. Scoring a goal or an own-goal against disease? A multilevel framework for describing metaphor coherence in health campaigns. Metaphor and the Social World 5(1). 102-123. https://doi.org/10.1075/msw.5.1.06ref

Entman, Robert M. 1993. Framing toward clarification of a fractured paradigm. Journal of Communication 43(4). 51-58. https://doi.org/10.1111/j.1460-2466.1993.tb01304.x

Goffman, Erving. 1974. Frame analysis: An essay on the organization of experience. Cambridge, Mass.: Harvard University Press.

Gradečak-Erdeljić, Tanja, \& Goran Milić. 2011. Metonymy at the crossroads: A case of euphemisms and dysphemisms. In Benczes, Réka \& Barcelona, Antonio \& Ruiz de Mendoza Ibáñez, Francisco (eds.), Defining metonymy in cognitive linguistics: Towards a consensus view, 147-166. Amsterdam: John Benjamins. https://doi.org/10.1075/hcp.28.08gra

Hertog, James K. \& McLeod, Douglas M. 2001. A multiperspectival approach to framing analysis: A field guide. In Reese, Stephen D \& Gandy, Oscar H. \& Grant, August W. (eds.), Framing public life: Perspectives on media and our understanding of the social world, 139-161. Mahwah, NJ: Lawrence Erlbaum.

Humphries, Harry L. \& Conrad, Browyn K \& Berry, Rimal \& Reed, Shelli \& Jennings, Clara Michelle. 2009. Framing the gift of life: An empirical examination of altruism, social distance and material incentives in non-directed kidney donor motivation. The Journal of Nephrological Social Work 31. 19-26.

Israel, Michael. 1997. The scalar model of polarity sensitivity. In Forget, Danielle \& Hirschbühler, Paul \& Martineau, France \& Rivero, María Luisa (eds.), Negation and polarity, 209-229. Amsterdam: John Benjamins.

Israel, Michael. 1998. The rhetoric of grammar: Scalar reasoning and polarity sensitivity. Doctoral Dissertation, San Diego: University of California.

Kahneman, Daniel \& Tversky, Amos. 1979. Prospect theory: An analysis of decision under risk. Econometrica 47. 263-292.

Kazoleas, Dean C. 1993. A comparison of the persuasive effectiveness of qualitative versus quantitative evidence: a test of explanatory hypotheses. Communication Quarterly 41(1). 40-50. https://doi.org/10.1080/01463379309369866

Kertész, András \& Rákosi, Csilla. 2008. Daten und Argumentation in der Theorie konzeptueller Metaphern. In Kertész, András \& Rákosi, Csilla (eds.), New approaches to linguistic evidence. Pilot studies / Neue Ansätze zu linguistischer Evidenz. Pilotstudien, 199-233. Frankfurt: Peter Lang.

Kertész, András \& Rákosi, Csilla. 2009. Cyclic vs. circular argumentation in the Conceptual Metaphor Theory. Cognitive Linguistics 20(4). 703-732. doi: $10.1515 / \operatorname{cog} 1.2009 .030$

Kövecses, Zoltán. 2002. Metaphor: A practical introduction. Oxford: Oxford University Press. 


\section{EZIKOSLOVLE \\ 21.3 (2020): 305-344}

Kövecses, Zoltán \& Ambrus, Laura \& Hegedűs, Dániel \& Imai, Ren \& Sobczak, Anna. 2019. The lexical vs. corpus-based method in the study of metaphors. In Bolognesi, Marianna \& Brdar, Mario \& Despot, Kristina (eds.), Metaphor and metonymy in the digital age, 149-173. Amsterdam: John Benjamins.

Kövecses, Zoltán \& Radden, Günter. 1998. Metonymy: Developing a cognitive linguistic view. Cognitive Linguistics 9. 37-77.

Kružić, Barbara \& Tanacković Faletar, Goran. 2019. Metafora, metonimija, frazem i eufemizam: o čemu govorimo kada govorimo o smrti? Jezikoslovlje 20(2). 391-418. https://doi.org/10.29162/jez.2019.14

Kühberger, Anton \& Schulte-Mecklenbeck, Michael \& Perner, Josef. 1999. The effects of framing, reflection, probability, and payoff on risk preference in choice tasks. Organizational Behavior and Human Decision Processes 78(3). 204-231.

https://doi.org/10.1006/obhd.1999.2830

Lakoff, George. 1987. Women, fire, and dangerous things. What categories reveal about the mind. Chicago: The University of Chicago Press.

Lakoff, George \& Johnson, Mark. 1980. Metaphors we live by. Chicago: University of Chicago Press.

Lauriola, Marco \& Russo, Paulo M. \& Lucidi, Fabio \& Violani, Cristiano \& Levin, Irwin P. 2005. The role of personality in positively and negatively framed health decisions. Personality and Individual Differences 38(1). 45-59.

https://doi.org/10.1016/j.paid.2004.03.020

Markert, Katja \& Nissim, Malvina. 2006. Metonymic proper names: A corpus-based account. In Stefanowitsch, Anatol \& Gries, Stefan Th. (eds.), Corpus-based approaches to metaphor and metonymy, 152-174. Berlin: Mouton de Gruyter.

McGregor, Lesley M. \& Ferguson, Eamonn \& O'Carroll, Ronan E. 2011. Living organ donation: the effect of message frame on an altruistic behaviour. Journal of Health Psychology 17(6). 821-832. https://doi.org.10.1177/1359105311423862

Moloney, Gail \& Walker, Ian. 2000. Messiahs, pariahs, and donors: The development of social representations of organ transplants. Journal for the Theory of Social Behaviour 30. 203-227. https://doi.org/10.1111/1468-5914.00126

Morgan, Susan E. \& Harrison, Tyler R. \& Chewning, Lisa \& Davis, LaShara \& DiCorcia, Mark. 2007. Entertainment (mis)education: The framing of organ donation in entertainment television. Health Communication, 22(2). 143-151. https://doi.org.10.1080/10410230701454114

Muñoz, Carmen Portero. 2011. 'Noun-noun euphemisms in the language of the late 2000s' global financial crisis." Atlantis 33. 137-157.

Parasuraman, A. \& Dhruv Grewal \& Ramu Krishnan. 2004. Marketing research. Boston: Houghton Mifflin.

Purewal, Satvinder \& van den Akker, Olga B. A. 2010. A study of the effect of message framing on oocyte donation. Human Reproduction 24(12). 3136-3143. 
https://doi.org/10.1093/humrep/dep342

Radden, Günter \& Kövecses, Zoltán. 1999. Towards a theory of metonymy. Panther, Klaus-Uwe \& Radden, Günter (eds.), Metonymy in language and thought, 17-59. Amsterdam: John Benjamins.

Reinhart, Amber Marie \& Marshall, Heather M. \& Feeley, Thomas Hugh \& Tutzauer, Frank. 2007. The persuasive effects of message framing in organ donation: The mediating role of psychological reactance. Communication Monographs 74(2). 229-255. https://doi.org/10.1080/03637750701397098

Ruiz de Mendoza, Francisco José. 2000. The role of mappings and domains in understanding metonymy. In Barcelona, Antonio (ed.), Metonymy and Metaphor at the Crossroads, 109-132. Berlin: Mouton de Gruyter.

Ruiz de Mendoza, Francisco José \& Peña Cervel, Sandra. 2002. Cognitive operations and and projection spaces. Jezikoslovlje, 3, 131-158.

Sallis, Anna \& Harper, Hugo \& Sanders, Michael. 2018. Effect of persuasive messages on National Health Service Organ Donor Registrations: a pragmatic quasi-randomised controlled trial with one million UK road taxpayers. Trials 19(1). 513. https://doi.org/10.1186/ s13063-018-2855-5.

Schweda, Mark \& Schicktanz, Silke. 2009. The "spare parts person"? Conceptions of the human body and their implications for public attitudes towards organ donation and organ sale. Philosophy, Ethics, and Humanities in Medicine: PEHM 4. 1-10. https://doi.org/10.1186/1747-5341-4-4

Semino, Elena \& Demjén, Zsófia \& Demmen, Jane. 2018. An integrated approach to metaphor and framing in cognition, discourse, and practice, with an application to metaphors for cancer. Applied Linguistics 39(5). 625-645.

https://doi.org/10.1093/applin/amw028

Shimazono, Yosuke. 2013. Accommodating a "foreign" organ inside the body: Posttransplant bodily experiences of Filipino kidney recipients. Ars Vivendi Journal 3. 2450.

Shutova, Ekaterina \& Sun, Lin. 2013. Unsupervised metaphor identification using hierarchical graph factorization clustering. Proceedings of the 2013 Conference of the North American Chapter of the Association for Computational Linguistics: Human Language Technologies, 2013, 978-988.

Shutova, Ekaterina \& Teufel, Simone \& Korhonen, Anna. 2013. Statistical metaphor processing. Computational Linguistics 39(2). 301-353.

https://doi.org/10.1162/COLI_a_00124

Silaški, Nadežda. 2011. Metaphors and euphemisms - the case of death in English and Serbian. Filološki pregled 38(2). 101-114.

Steen, Gerard J. 2007. Finding metaphor in grammar and usage: A methodological analysis of theory and research. Amsterdam: John Benjamins. 


\section{EZIKOSLOVLEE \\ 21.3 (2020): 305-344}

Steen, Gerard J. \& Dorst, Aletta G. \& Herrmann, J. Berenike \& Kaal, Anna A. \& Krennmayr, Tina \& Pasma, Trijntje. 2010. A method for linguistic metaphor identification: From MIP to MIPVU. Amsterdam: John Benjamins.

Steen, Gerard J. \& Dorst, Aletta G. \& Herrmann, J. Berenike \& Kaal, Anna A. \& Krennmayr, Tina \& Pasma, Trijntje. 2010. A Method for linguistic metaphor identification: From MIP to MIPVU. Amsterdam: John Benjamins.

Stefanowitsch, Anatol. 2004. HAPPINESS in English and German: A metaphorical-pattern analysis. In Achard, Michel \& Kemmer, Suzanne (eds.), Language, culture, and mind, 137-149. Stanford: CSLI Publications.

Stefanowitsch, Anatol. 2006. Corpus-based approaches to metaphor and metonymy. In Stefanowitsch, Anatol \& Gries, Stefan Th. (eds.), Corpus-based approaches to metaphor and metonymy, 1-16. Berlin: Mouton de Gruyter.

Steffel, Mary \& Williams, Elanor F. \& Tannenbaum, David. 2019. Does changing defaults save lives? Effects of presumed conssent organ donation policies. Behavioral Science and Policy 5(1). 68-88. https://doi.org/10.1353/bsp.2019.0005

Studts, Jamie L. \& Ruberg, Joshua L. \& Mcguffin, Sarah A. \& Roetzer, Lynne M. 2010. Decisions to register for the National Marrow Donor Program: rational vs emotional appeals. Bone Marrow Transplantation 45(3). 422-428.

Taylor, Robert B. 2017. The amazing language of medicine. Understanding medical terms and their backstories. New York: Springer.

Thibodeau, Paul H. 2016. Extended metaphors are the home runs of persuasion: Don't fumble the phrase. Metaphor and Symbol 31(2). 53-72. https://doi.org/10.1080/10926488.2016.1150756

Thompson, Erin. 2003. The framing of organ and tissue donation - a framing analysis of the nation's elite newspapers. Doctoral dissertation, University of Florida.

Wallington, Alan M. \& Barnden, John A. \& Barnden, Marina A. \& Ferguson, Fiona J. \& Glaseby, Sheila R. 2003. Metaphoricity signals: A corpus-based investigation. Birmingham: School of Computer Science, The University of Birmingham, U.K.

Zillmann, Dolf. 1999. Exemplification theory: Judging the whole by the sum of its parts. Media Psychology 1(1). 69-94. https://doi.org/10.1207/s1532785xmep0101_5

Zillmann, Dolf. 2002. Exemplification theory of media influence. In Bryant, Jennings \& Zillmann, Dolf (eds.), Media effects: Advances in theory and research, 213-245. Mahwah, NJ: Lawrence Erlbaum.

Zillmann, Dolf, \& Brosius, Hans-Bernd. 2000. Exemplification in communication: The influence of case reports on the perception of issues. Mahwah, NJ: Lawrence Erlbaum. 


\section{Authors' addresses:}

Mario Brdar

Faculty of Humanities and Social Sciences, University of Osijek

L. Jägera 9

31000 Osijek

E-mail: mbrdar@ffos.hr

Rita Brdar-Szabó

Eötvös Loránd University

Rákóczi út 5

1188 Budapest

E-mail: szabo.rita@btk.elte.hu

\section{ULOGA METAFORA I METONIMIJA \\ U UOKVIRIVANJU DISKURSA TRANSPLANTOLOGIJE}

U prilogu se proučava figurativna uporaba metafora i metonimija u uokvirivanju diskursa transplantologije. Polazimo od šireg shvaćanja pojave uokvirivanja od onog koje je općeprihvaćeno u literaturi te tvrdimo da se toj pojavi može pristupiti kao kontinuumu s dva pola: osobnom i institucionalnom. Ovaj se pristup kombinira s teorijom izglednosti unutar koje se postulira gubitno i dobitno uokvirivanje kao dvije strateške mogućnosti izbora. Kako bi bila svrsishodna, sredstva koja se rabe za uokvirivanje, kako pokazujemo na autentičnim materijalima, trebaju se prilagoditi odsječku kontinuuma na koji se može smjestiti određeni podtip diskursa. Iako je u kognitivno lingvističkoj literaturi naglasak gotovo uvijek na ulozi metafore u uokvirivanju diskursa, ističemo da i doprinos metonimije, u suradnji s metaforama, može biti od velikog značaja. Sredstva koja se rabe zauokvirivanje u javnim kampanjama kojima je cilj pridobivanje novih donora organa u pravilu se temelje na konceptualnoj metafori POKLONA. Pokazuje se da metaforička uporaba koncepta POKLONA kao globalnog izbora $\mathrm{u}$ institucijskim kontekstima nije učinkovita jer je preopćenita i neodređena a da bi mogla biti uvjerljiva na osobnom nivou, kao što se i može predvidjeti u okviru teorije oprimjerivanja. Spomenuta je metafora učinkovitija kada se prikladno prilagodi, kako pokazujemo na nekim primjerima kampanja koje su poduprte ili se temelje na metonimijskom prikazu različitih aspekata koji naglašavaju kvalitetu života nakon transplantacije.

Ključne riječi: metafora; metonimija; uokvirivanje; zdravstveni diskurs. 